\title{
Effect of Different Levels of Sewage Sludge on Concentration of Heavy Metals Soil Grow With Cereal Crops
}

\author{
${ }^{1}$ Abubaker Mohamed Outhman ${ }^{*},{ }^{2}$ Ram Bharose \\ Department of Environmental Science, School of Forestry \& Environment, SHIATS, Deemed \\ University, Allahabad \\ *PhD student, .Associate professor on Department of Environmental Science, School of Forestry \& \\ Environment, SHIATS, Deemed University, Allahabad
}

\begin{abstract}
The aim of this study to investigate the effect of different levels of sewage sludge on concentration of heavy metals like $\mathrm{Zn}, \mathrm{Cr}, \mathrm{Ni}, \mathrm{Cu}$. In soil which grow with two cereal crops (Barley Hordem vulgare $L$ \& wheat Triticum aestivum) the study was on the field of department of environment science school of Forestry\& Environment SHIATS. To investigate the effect four dose of sewage sludge $\left(0,4,8\right.$ and 12 ton $\left.h^{-1}\right)$ were applied in a sandy loam soil for to seasons the soil samples taken from the $(0-15 \mathrm{~cm})$ soil depth. The concentrations of $\mathrm{Cr}, \mathrm{Zn}, \mathrm{Ni}$ and $\mathrm{Cu}$ were determined from the study area. Experimental results showed that the concentration of these heavy metals were increase when the dose increase the highest concentrations was in the 12 ton $h^{-1}$ and the significant correlation between heavy metal concentration and sewage sludge increase dose.
\end{abstract}

Key words: sewage sludge, soil, heavy metals, cereal crops.

\section{Introduction}

The environment is the most important things in our life because we use resource to make our life better, whereas in same time we produce many things that harm the environment and all that comes from ignorance of people about consequence of their acts and their selfish. Today all the world feels about the environment even he realize that he need to use the natural resource, there are many problem that makes the human thinks deeply before doing his activity to get big benefits and release less pollutants. As we know the human will use natural resource to supply enough requirements, but while that he will produce more and different pollutants, the sewage sludge one of major source of nutrients and pollutant [18],[3] and it's contain some of heavy metals that make it source of soil pollution if apply to cropland Heavy metals do not degrade by biochemicalprocesses due to resistance to microbial degradation and may be bioaccumulated and biomagnified along the food chain [7]. Use of sewage sludge in agriculture is the most convenient practice of sludge disposal. Heavy metals from the major group of toxic pollutants among the other pollutants, it contains heavy metals, which may have adverse effects on crops and possibly humans [14]. as these metals temper the harmony of the ecosystem (Rao and Patnaik, 1999). use of sewage sludge in agriculture as a partial substitute of mineral fertilizers (Mona et, al,2013) the regular application of sewage sludge leads to built heavy metal in soil [12].

\section{Material And Method}

The field study was carried out in wheat, barley experimental at fields of school of forestry and Environment, Sam Higginbottom Institute of Agriculture \& Technology Sciences -Deemed to be- University Allahabad from October 2012 to April 2014,

\section{Selected Experimental Site:}

The field experiments plans to lay out on the Research farm of Department of Environmental Science, School of Forestry and Environment, SHIATS, Allahabad. The area is situated on the right bank adjacent to Yamuna River in south of Allahabad city, which is located at $25^{\circ} .80^{\prime} \mathrm{N}$ Latitude and $81^{\circ} .50$ E Longitude and 98 meter above the sea level.

\section{Land Preparation}

The experimental field will be plan to prepared by ploughing twice with a tractor drawn disc plough followed by cross harrowing after one irrigation to give the soil sufficient moisture required for the germination of the crop. The field was thoroughly leveled by a leveler. The ploughed field will be leveled and weeds, grasses are then removes with the help of rake, and then demarcation are complete according to the layout.

Treatment Combination

$\mathrm{T}_{1}=00.00$ Tonnes Sewage sludge + Barley crop

$\mathrm{T}_{2}=04.00$ Tonnes Sewage sludge + Barley crop 
$\mathrm{T}_{3}=08.00$ Tonnes Sewage sludge + Barley crop

$\mathrm{T}_{4}=12.00$ Tonnes Sewage sludge + Barley crop

$\mathrm{T}_{5}=00.00$ Tonnes Sewage sludge + Wheat Crop

$\mathrm{T}_{6}=04.00$ Tonnes Sewage sludge + Wheat Crop

$\mathrm{T}_{7}=08.00$ Tonnes Sewage sludge + Wheat Crop

$\mathrm{T}_{8}=12.00$ Tonnes Sewage sludge + Wheat Crop

\section{Statistical Analysis}

Randomized block design was used for statistical analysis or 8 treatment combinations tested in a RBD with 3 replications .

\section{Soil Sampling}

The soil samples will collect randomly from 0-15 soil depth and The samples will be mixed and its weight is reducing by air drying, conning, quartering and passing it through $2 \mathrm{~mm}$ sieve.

\section{Analysis Of Heavy Metals In Soil Samples}

Heavy metals in soil samples will be determines by the method of [1],[2], as described below. In the laboratory Soil samples will be dry at $40^{\circ} \mathrm{C}$ for 48 hours in the hot oven and then crush with wooden hammer to pass through $2 \mathrm{~mm}$ sieve. A di-acid mixture is required to extract out the heavy metals present in the soil. A known amount $(5 \mathrm{~g})$ of oven dry soil sample transfer into $100 \mathrm{ml}$ beaker to which $30 \mathrm{ml}$ of $4: 1\left(\mathrm{Conc} \mathrm{HNO}_{3}\right.$; $\left.\mathrm{HClO}_{4}\right)$ mixture will be add. The mixture is place on a hot plate at $105^{\circ} \mathrm{C}$ for one hour and then temperature is increase to $140^{\circ} \mathrm{C}$ until the sample completely dry. After cooling the solution mix it and filter through Whatman No. 42 filter paper into a $50 \mathrm{ml}$ volumetric flask rinse and make up to volume $50 \mathrm{ml}$ with double distilled water. Digested samples are then analyzed for presence of heavy metals on Atomic Absorption Spectrophotometer (A.A.S.)

\section{Result And Discussion}

Effect of different levels of sewage sludge on concentration of heavy metals soil grow with cereal crops, the result shown the clearly effect on heavy metals that covered by study ( $\mathrm{Zn}, \mathrm{Cr}, \mathrm{Ni}, \mathrm{Cu}$ ), many studies consider that the apple of sewage sludge increase some of pollutant such as heavy metal [11].

\section{Zinc}

The data presented in fig (1) clearly shows that the concentration is increase with increase in sewage sludge dose and the high concentration was $3.12 \mathrm{ppm}$ and the lower concentration was $2.71 \mathrm{ppm}$ [16] because the sewage sludge contains higher amount of heavy metals, on the first season the concentration was 2.712 with (0) of sewage and it's increase Gradually with increase on sewage sludge dose These results are similar to those obtained by [6], [8], [13] reported that use of sewage sludge increase the $\mathrm{Zn}$ in the soil and the continues use of sewage sludge improvement heavy metal state .

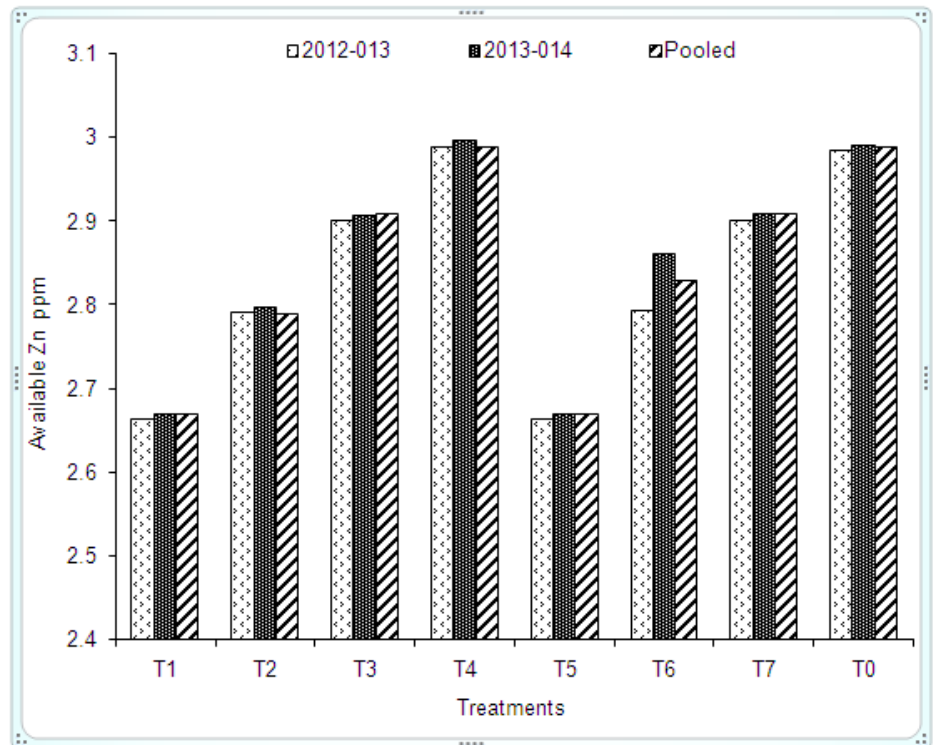

Fig. (1)Effect Of Sewage Sludge On Available Zn Ppm Of Past-Harvest Soil At 0-15cm 


\section{Chrome}

The following figure (2) present a effect of different rate of sewage sludge on $\mathrm{Cr}$ concentration in soil after harvest, the high concentration was in highest dose of sewage sludge, were the range of $\mathrm{Cr}$ concentration on soil sample between $1.826-3.09 \mathrm{ppm}$ and the high concentration was on 12 ton $\mathrm{ha}^{-1}$ on other hand the increase of concentration happen on the second season of study similar finding had also been reported by [18]. and accordance with the finding of [9],[5] .

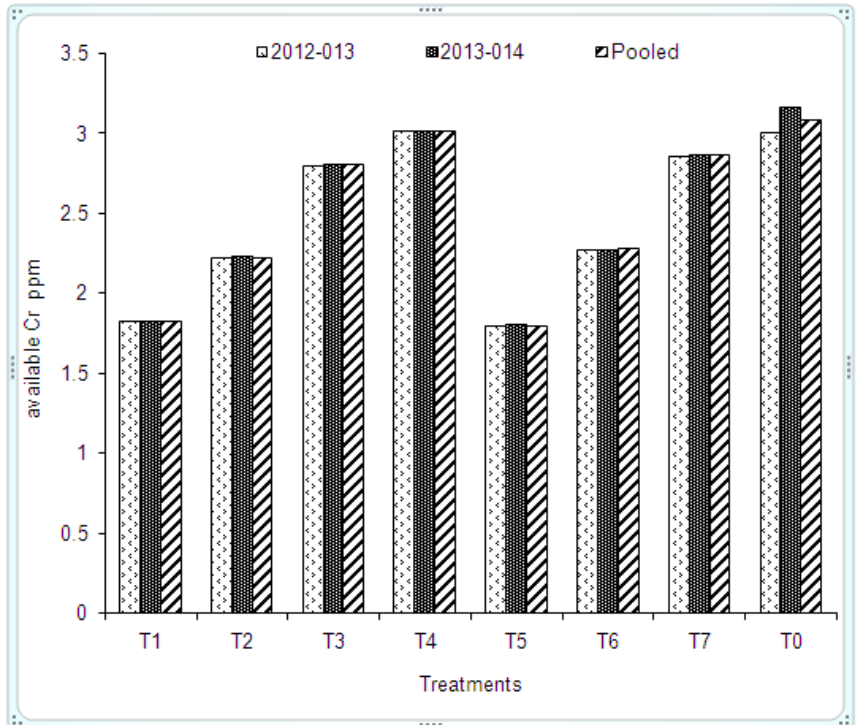

Fig (2) Effect Of Sewage Sludge On Available Cr Ppm Of Past-Harvest Soil At 0-15cm

\section{Nickel}

The present result show the significant effect of apply sewage sludge on the nickel concentration on soil samples after harvesting were the concentration range of nickel between 1.028 -1.09 ppm and the highest rate was on the 12 ton $\mathrm{ha}^{-1}$ this is in the line with other studies that reported and the concentration of nickel on the second season is increasing with sewage sludge dose increase the same result was also given by [17], [15].

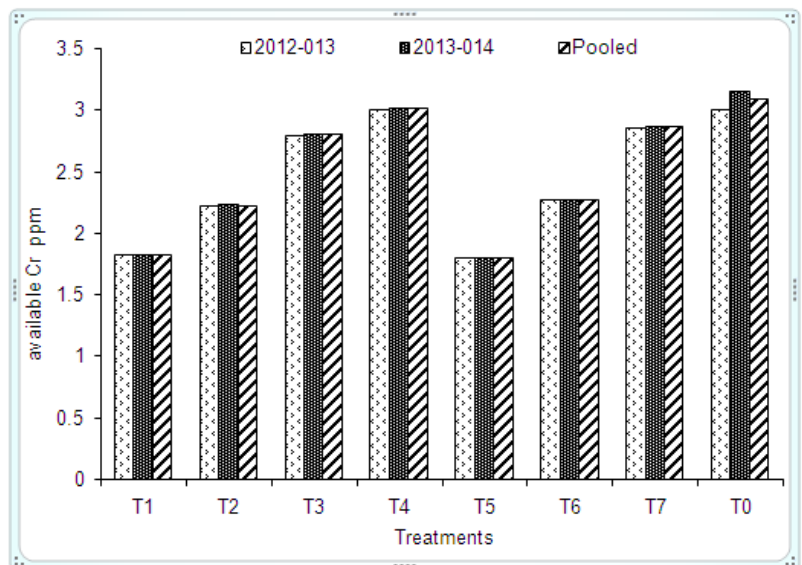

Fig (3) Effect Of Sewage Sludge On Available Ni Ppm Of Past-Harvest Soil At 0-15cm

\section{Copper}

The following figure present clearly effect of sewage sludge on copper concentration on soil after harvesting on two seasons were the concentration range of cupper between $1.184-1.811 \mathrm{ppm}$ and the concentration is increase in the second season were the rang was between $1.189-1.817$ the similar result had been reported by [10],[19] . 


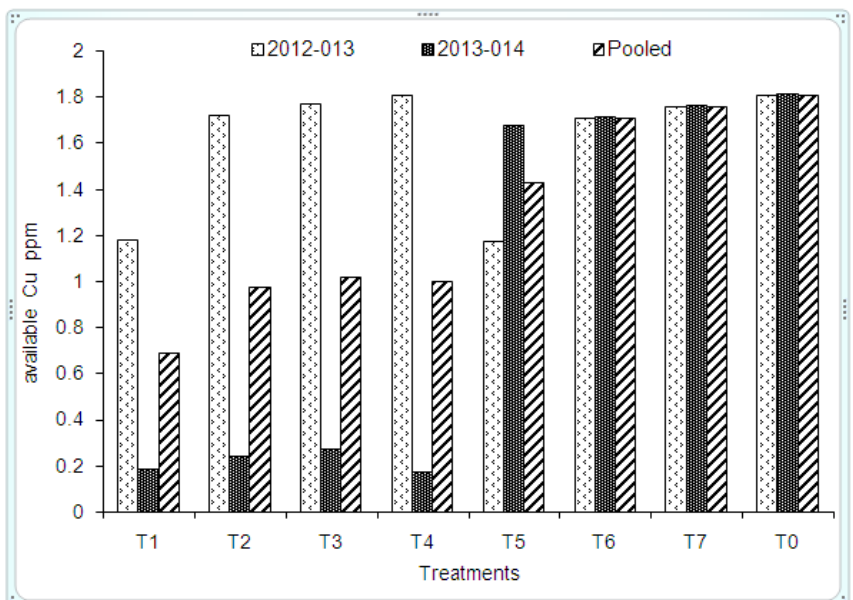

\section{Fig (4) Effect Of Sewage Sludge On Available Cu Ppm Of Past-Harvest Soil At 0-15cm}

\section{Summary \& Conclusion}

The effect of sewage sludge on land crops is clearly present as result of it use, the concentrations of heavy metals is increase with increase of sewage sludge dose and the concentrations are increase on the second season, the statistic analysis indicate the significantly effect on two seasons and between doses. the heavy metals introduced with the sludge were substantially higher at 12 ton ha-1

\section{References}

[1]. Black, C. A. (1965) Methods of soil analysis part-2 chemical and microbiology properties -Amer .Soc. agron Madison, Wisconsin. U.S.A.

[2]. Lindsay, W. L. and Norvell, W. A. (1978) Soil Sci. Soc. Am. J. 42, pp 421.

[3]. Hoffmann,G.,Daniel,S. and Barnd, B.(2010) comparing different methods of analyzing sludge, dewatered sludge and sludge ash. [4]Desalination, 250: 399-403

[4]. Kharche, V.K; Desai V.N and pharande, A.L(2012) Effect of sewage irrigation on soil properties, essential nutrients and pollutant element state of soil and plant in vegetable growing area around Ahmed Nager city in Maharashtra. Journal of the Indian society of soil Science, Vol.59

[5]. (2) PP-177-184

[6]. Korack, R.F. and D.S. Fannings. (1985). Availability of applied heavy metals as a function of type of soil material and metal source. Soil Sci., 140: 23-34

[7]. LIAO, Y.C. et al. (2006) Effect of transpiration on Pb uptakeby lettuce and on water soluble low molecular weight organic acids in rhizosphere. Chemosphere, Amsterdam, v.65, n.2, p.343-351,

[8]. Meena, M.C., Patel, K.P, Singh Dhyan and Dwivedi, B.S.(2008) Long term effect of sewage sludge and farmyard manure on grain yields and availability of zinc and Iron under pearl millet (Pennisatum glaucum)- Indian mustard (brassica juncea) cropping sequence. Indian journal of Agriculture science, 78(12):1028-32

[9]. Nascimento, C.W.A., Barros, D.A.S., Melo, E.E.C. and Oliveira, A.B.(2004)

[10]. Soil chemical alterations and growth of maize and bean plant after sewage sludge application. Revista Brasileira de ciencia do Solo,28(2):385-392.

[11]. O. Dikinya; O. Areola (2010) Comparative analysis of heavy metal concentration in secondary treated wastewater irrigated soils cultivated by different crops Int. J. Environ. Sci. Tech., 7 (2), 337-346

[12]. Passuello, A., Cadiach, O., Perez, Y., Schuhmacher, M., (2012). A spatial multicriteria decision making tool to define the best agricultural areas for sewage sludge amendment. Environ. Int. 38, 1-9.

[13]. Radha, K, Tabey, S. S. and Poveda, J. (2004) Effect of sewage irrigation some heavy metal content in soil, water and plant. Journal Agriculture Science 18(8): 2493-2502

[14]. Shuman, L.m. (1999). Organic waste amendments effect on Zn fractions of two soils. J.Environ. Qual. 28:1442-1447.

[15]. Solar-Rovira, P., Soler-Soler, J., Solar-Rovira, J. and Polo, A.: (1996), 'Agricultural use of sewage sludge and its regulation', Fertilizer Research 43, 173-177.

[16]. Topcuoglu, B. (2005) Effect of repeated Applications of sewage sludge and MSW Compost on the Bioavailability of Heavy Metals in Greenhouse Soil. Poilsh journal of Environmental Studies 14:217-222.

[17]. ANTONIADIS and B. J. ALLOWAY,(2001). Water, Air, and Soil Pollution 132: 201-214.

[18]. Wang, P. E., Li, Q. Z., and shuman, L.M (1997) Fractions and availability of Ni in Loessial soils amended with sewage or sewage sludge. J. Environ. 26:795-801.

[19]. Yongjie Wei, Yangsheng Liu ,(2005), Effects of sewage sludge compost application on crops and cropland in a 3 -year field study, Chemosphere 59 (2005) 1257-1265

[20]. E. E. Awokunmi, S. S. Asaolu1 and K. O. Ipinmoroti (2010), Effect of leaching on heavy metals concentration of soil

[21]. in some dumpsites African Journal of Environmental Science and Technology Vol. 4(8), pp. 495-499 